\title{
Polite Requests of Indonesian Learners of FLE and French Native Speakers: An Interlanguage Study
}

\author{
Elvi Syahrin ${ }^{1}$, Tengku Silvana Sinar ${ }^{2}$, Eddy Setia $^{2}$, Nurlela $^{2}$ \\ ${ }^{1}$ Universitas Negeri Medan, Medan, Indonesia \\ ${ }^{2}$ Universitas Sumatera Utara, Medan, Indonesia \\ syahrin@unimed.ac.id
}

\section{Abstract}

This study anchored in the field of Interlanguage Pragmatic (ILP). The approach taken is speech act based. The investigation focuses on realization of polite requests produced by Indonesian learners of Français langue étrangère (FLE) (henceforth abbreviated as $I L F)$ and native speakers of French (henceforth abbreviated as $N S F)$. The model used for the investigation is the Cross-Cultural Speech Act Realization Project (CCSARP) model formulated by Blum-Kulka et al. (1989), modified by Warga (2005) and Bae (2012). The model applied to the analysis of the data is based on three politeness systems of social relationship between speaker and addressee proposed by Scollon and Scollon (2001). Data was be collected by using Written Discourse Completion Test (WDCT). Six out of twelve request situations formulated by Reiter (2000) categorized into each politeness system were selected to be analyzed. The WDCT were tested to 20 ILF; 1 learner of Universitas Negeri Medan and 19 learners of Universitas Negeri Jakarta. The 20 participants are those who are certified of Diplôme d'études en langue française (DELF) of B2 level (advanced level). As the baseline data of the study, the e-mailed data of $20 \mathrm{NSF}$ were also collected. The study found that there is a preference of Indonesian learners of FLE and native speaker of French to use Conventional Indirect strategy in their requests. This strategy, even realized in slightly different number of use, was highly used and considered to be the most polite request by the two groups.

\section{Keywords}

politeness;

requests;

Indonesian learner;

French native

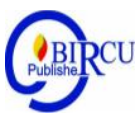

\section{Introduction}

Learning a language, whether as a second language or foreign language, is not only a matter of dealing with the acquisition of vocabulary, phonetics and morphosyntax of the language learned solely in isolated structures. It is also the matter of understanding and awareness of the use of these elements in different contexts with speakers of different mother tongues. This idea is in lines with the idea of Warga (2005) stating that a successful language learners need to master the rules of using the elements. In order to convey a successful communication, a language learner needs to engage with pragmatic competence.

The performance of speech acts is not always an easy task for learners of second languages, because the ways to deliver a request, for example, is governed by social conventions and therefore the actual implementation of those acts of language requires not only language skills but also sociopragmatics skills. Even the second language learners of advanced level often fail to accomplish the speech-acts efficiently and socially appropriate in the target language and lags far behind native speakers in several respects. (Thomas, 1983; Blum-Kulka, 1983; Kasper, 1984; Olshtain \& Blum-Kulka, 1985, Bella 2012). Politeness as one important issue in pragmatic seems to be an important device in order to carry out 
successful communication and has a prominent role in reflecting learners' communicative competence. It is well known that politeness is often realized by indirectness strategy (Leech, 1983). The use of this strategy not only enable speaker to save speaker's face, furthermore it can also intentionally be used as tool to attack hearer's face (Grainger 2011; Tannen 2010; Kiesling and Johnson 2010).

The present research aims to contribute to attaining a clearer picture of Indonesian learners of FLE politeness performance in speech acts of request by examining the strategies used especially the use of indirectness strategy. It is triggered by the fact that there is still little attention, if not none, paid to investigate Indonesian learners of FLE especially to their pragmatics production of polite request. Hence, this study would fill the theoretical gap about Indonesian learners of FLE compared to native speaker of French that apparently never been investigated.

\section{Research Method}

This work implements qualitative approach. The research participants are taken purposively based on their avaliability. They are 20 students of the Department of French; 1 student of the Universitas Negeri Medan and 19 students of the Department of French of Universitas Negeri Jakarta who certified of B2 (intermediate level) of DELF (Diplôme d'études en langue française) according to the Common European Framework of Reference for Languages (CECRL).

As the baseline of the study, Data of native speakers of French is gathered by e-mail from 20 native speakers of French aged 24 - 55 years old living in France; Marseiile, Metz, Lyon, la Rochelle, Saint Aunès, Caen, Bayonne, et Lorraine.

Data is collected by using the form of an open-ended written discourse completion test (WDCT). The questionnaire used in this investigation involved six out of twelve written context-enriched situations developed by Reiter (2000) modified by using three politeness systems of social relationship between speaker and addressee proposed by Scollon and Scollon (2001): (a) hierarchical politeness system, (b) deferential politeness system, and (c) solidarity politeness system.. In each of the situation, the information was given on the requestive goal, social distance, social dominance, the role-relationship, the length of acquaintance, the frequency of the interaction, and a description of the setting. Each situation could only be answered by a request.

Request were analysed for the occurrence of request strategies in the head act of the request that is the core part of the request sequence which realizes a request independently of other elements (Blum-Kuka et al. 1989).

\section{Discussion}

\subsection{Results}

The following sections present the analysis of request strategies used by Indonesian learners of FLE and Native speakers of French with regard to strategies used based on level of indirectness of request. Overall there are 240 requests analysed under investigation.

a. Politeness in Deference Politeness system

Situation 1

(-P/+D/R Low)

Speaker asks bus passenger to swap seats 
In the situation where the speaker has equal power and relatively big distance with the addressee, and low rank of imposition, both groups prefer to realize their request in indirect conventional in particularly with query preparatory with question sur la capacité (ILF 55\% NSF 25\%), question sur la possibilité (ILF 5\% - NSF 35\%) and question sur la disponibilité (ILF 5\% - NSF 20\%).

1) Query preparatory with question sur la capacité:

ILF: Pourriez-vous échanger la place avec la mienne? (R13)

'Could you change your seat with mine?'

NSF: Pourriez-vous me laisser la double place. (R137)

'Could you let me (get) the double-seat?'

2) Query preparatory with question sur la possibilité:

ILF: Est-ce que c'est possible si je vous demande de changer de chaise avec moi? (R20) 'Is it possible if I ask you to change seat with me?'

NSF: Serait-il possible que nous intervertissions nos places... ?. (R124)

'Would it possible if we switch our seats?'

3) Query preparatory with question sur la disponibilité:

ILF: Avez-vous le plaisir pour remplacer le siège vide là-bas? (R1)

'Could you change your seat with mine?'

NSF: Auriez-vous la gentillesse de prendre la place libre qui est à côté ?.

'Do you have kindness as to take an available seat next to you?'

Even with slightly different number of use of question types, it seems that the learner of FLE and native speaker of French understand that Préparation (query preparatory) is the most effective way to convey this type of request. However it is found that Indonesian learners of FLE chose type of questions that were not use by native speakers namely question sur la volonté (20\%) and question sur la permission (10\%).

4) Query preparatory with question sur la volonté:

Est-ce que vous voudriez vous asseoir à cote du jeune garçon la? ? (R2)

'Would you like to sit close to that young boy?'

5) Query preparatory with question sur la permission:

Pourrais-je assesoir là avec mon fils?

'Could I sit with my boy?'

Oppositely, native speaker of French prefer formule ritualisée (ritual formulation) (20\%). This is the type of query preparatory sub strategy that was not chosen by Indonesian learners of FLE for this situation.

Ça vous dérangerait de changer de place avec moi? (R121)

'Do you mind changing seat with me?'

Interestingly, Indonesian learner of FLE chose Formule Suggestive (Suggestory formulae) to promote politeness in the request:

ILF : Si vous voulez change votre chaise? (R18)

'If you want to change your seat?'

Situation 2

(-P/+D/R High)

Speaker asks a neighbour for help to move out of flat using his/her car.

Similar to previous data, there is a great use of indirect conventional strategy on ILF and NSF in this situation. Accordingly, ILF and NSF share the use of query preparatory with slightly equal use of question sur la capacité (ILF 50\% - NSF 40\%), question sur la 
possibilité (ILF 5\% - NSF 5\%) and question sur la disponibilité (ILF 5\% - NSF 15\%) and small different number of use in permission ((ILF 25\% - NSF 5\%)

1) Query preparatory with question sur la capacité:

ILF: Est-ce que vous pourriez me prêter la votre? (R22)

'Could you lend me yours?'

NSF: Pourriez-vous me donner un coup de main pour aménager dans mon appartement? (R153)

'Could you give a hand to move into my apartment?'

2) Query preparatory with question sur la possibilité:

ILF: Est-ce que c'est possible vous me pretez votre voiture monsieur? (R27)

'Is it possible if you lend me your car, sir?'

NSF: Est-ce que ce serait possible que j'emprunte votre voiture (R150)

'Would it be possible if I borrow your car?'

3) Query preparatory with question sur la disponibilité:

ILF: Est-ce que vous avez le temps? (R38)

'Do you have time?'

NSF: Est-ce que vous seriez libre pour m'aider à descendre le meuble? (R155)

'Would you be available to help me to move out the furniture?'

4) Query preparatory with question sur la permission:

ILF: Pourrais-je utiliser votre voiture? (R39)

'Could I use your car?'

NSF: Je peux emprunter un petit peu de votre temps que vous m'aidiez? (R158)

'Can I borrow a bit of your time to help me?'

It is found that, again, Indonesian learners of FLE chose question sur la volonté (20\%). This type of question was never been found in the data of native speakers of French in this situation.

5) Query preparatory with question sur la volonté:

Voudriez vous m'aider? ? (R31)

'Would you like to help me?'

In contrast, NSF opt formule ritualisée (ritual formulation) (25\%).

Ça vous dérangerait de changer de place avec moi? (R121)

'Would you mind changing seat with me?'

The formule ritualisée is the formulation commonly employed by native speaker of French who has equal power, relatively big distance with the addressee, and with high rank of imposition. It belongs to polite register. Indonesian learners of French never use this kind of formulation due to lack of language stimulus in classroom.

Accordingly to soften the request, NSF use Formule Suggestive (Suggestory formulae) in their request, as following example:

Si vous pourriez me rendre ce service? (R149)

'If you could help me?'

NSF deliberately uses also non-conventionally indirect strategy or hints in this situation.

NSF: Il faudrait que je porte des affaires à la déchetterie et je n'ai pas de voiture. (R142)

'I had to take these things to the dump'

In this case, NSF delivers the request by promoting the urgency of the action that have to be executed promptly. NSF use hints as a means to reduce the weight of the request.

It can be concluded that in the deference politeness system where distance between speaker and addressee is relatively big, there is a preference of Indonesian learners of FLE 
and native speaker of French to use Conventional Indirect strategy in their request for example when asking to swap seats to stranger in the bus or asking help to a neighbour whom the speaker not so familiar with. Eventually, this strategy, even realized in slightly different number of use is considered to be the most effective polite way to deliver a request.

\section{b. Politeness in Solidarity Politeness System}

Situation 3

(-P/-D/R Low)

Speaker is driving and asks his/her friend to ask someone for direction

The data shows the use of indirect conventional strategy on ILF and NSF in this situation. ILF and NSF mutually use query preparatory with question sur la capacité (ILF $40 \%$ - NSF 55\%), as the only type of question used in this situation.

1) Query preparatory with question sur la capacité:

ILF : Tu peux demander à cet damme où est la rue de Merpati 25 ? (R48)

'Can you ask that lady where Merpati 25 street is?'

NSF: Tu peux demander au piéton la direction? (R170)

'Can you ask a direction to the pedestrian?'

The data show remarkably use of direct strategy of Mode Derivable (imperative) in both groups (ILF 35\% - NSF 30\%) and that of obligation statements (ILF 5\% - NSF 10\%).

2) Mode Derivable (Imperative):

ILF : Demande à cet homme de cette adresse. (R41)

'Ask the address to the man.'

NSF: Va demander au piéton du bout de la rue, le chemin. (R176)

'Let's ask the pedestrian on the corner, the address.'

3) Obligation statements:

ILF : On doit demander à quelqu'un. (R49)

'We have to ask somebody'

NSF: Tu devrais demander à ce piéton de nous indiquer où se trouve la rue 'X' (R168)

'You have to ask the pedestrian to show us where street ' $x$ ' is.'

The possible reason of the use of imperative and obligation statements is, primarily due to the closeness of speaker and addressee that in this case is his/her friend and secondly, due to the urgency of the request that has to be fulfilled promptly, and thirdly the risk that would possibly happen if the action is not conducted.

Interestingly, this study found the request that is not match to any types of requests strategy applied in the study. These requests produce by both ILF and NSF that can be observed in the followings.

ILF: pourquoi tu ne demande pas à lui ? (R54)

'why don't you ask him?'

The speaker delivers the request indirectly to the addressee by using negativeinterrogative form of request. The request can possibly put the addressee to some inconvenience by the fact that he/she has done some mistakes by not asking the address to the man at the first place. In this situation, the speaker put the task to the addressee as if it is the responsibility of addressee himself. This kind of request is considerably impolite especially when it is expressed in a high tone of voice.

The kind of uncommon form of request is also found in the request of NSF that can be seen in the following example:

NSF: Tiens, tu n'as qu'à demander à ce piéton! (R167) 
'Look, all you have to do is ask the pedestrian!'

In this case, the speaker expresses the request by insisting that the action is quite easy to accomplish. It seems that the speaker intends to encourage the addressee rather than to minimize the face-threaten act of the request.

Situation 4

(-P/-D/R High)

Friend asks another friend to borrow his/her house in the country side

Both groups prefer to realize their request in indirect conventional in particularly with query preparatory with question sur la capacité (ILF 5\% - NSF 30\%), question sur la possibilité (ILF 10\% - NSF 30\%) and question sur la permission (ILF 60\% - NSF 10\%).

1) Query preparatory with question sur la capacité:

ILF: Peux-tu me laisser rester dans ta maison qui se trouve à la campagne? (R70)

'Can you let me stay in your house in the countryside?'

NSF: Est-ce que éventuellement tu pourrais me prêter pour une petite semaine à ta maison en Camargue? (R195)

'Could you eventually lend me this short week your house in Camargue?'

Although this type of question is used frequently by ILF in many situations, it is not the case found in the data of this situation. There is only one request using question sur la capacité. This is possibly because for ILF a house is rather a personal place that is usually not shareable in Indonesian culture.

2) Query preparatory with question sur la possibilité:

ILF: Est-ce que ce possible que je reste à ta maison pour une semaine? (R65)

'Is it possible if I stay in your house for a week ?'

NSF: Ce serait possible que je l'occupe la dernière semaine? (R181)

'Would it be possible if I occupy it during the final week?'

In contrast, ILF tend to use question sur la permission massively in their requests. They use this type of question far more than NSF do.

3) Query preparatory with question sur la permission:

ILF: Je peux y rester pour me détendre? (R79)

'Can I stay to relax?'

NSF: Est-ce que je pourrais rester là-bas pendant une semaine avec ma femme? (R199) 'Could I stay there for a week with my wife?'

The fact that NSF tends to chose question sur la capacité and question sur la possibilité considering that this kind of request is possibly due to the acceptability in their culture. In line with that NSF has a great preference in using formule ritualisée (ritual formulation). Furthermore, NSF use hints that might be considered as polite request.

Surprisingly, it found that ILF employ direct strategy by the use of Want and Need statements. This is quite crucial considering the rank of imposition in this situation is considerably high.

Want and need statement by ILF:

Je voudrais rester à votre maison à la campagne pour diminuer le stress. (R68)

(I want to stay in your house in the countryside to reduce the stress).

In this request situation, it is found requests that cannot be categorized in the formulation of request used in the study. These requests produce by both ILF and NSF that can be observed in the followings.

ILF: tu vas me laisser d'y rester au moment duquel tu n'es pas là, n'est-ce pas? (R62) 
'You will let me stay there when you're not there, right?'

This type of request brings a threat to addressee because the speaker does not give choices for addressee to reconsider the request. Even formulated in the form of query preparatory it is obviously not a polite way of expressing request. The research also found the Negative-interrogative formulation of request produced by ILF as shown in following example:

ILF: Pourquoi pas tu ne me laisse pas pour se détendre à ta maison? (R74)

'Why don't you let me relax in your house?'

This kind of request seems peculiar for it is not common, if not never, been spoken by native speaker of French. The presence of the formulation is possibly due to the influence of other language learned by the Indonesian learner of French i.e. English with pattern of 'why don't you?'

The data from NSF show the use of query preparatory with question of "agreement" with the verb 'accepter' as following example:

Est-ce que tu accepterais de me louer ta maison de campagne pendant une semaine... ? (R183)

'Would you agree to rent me your country house for a week ...?'

This type of request shows the sincerity of speaker that could be the "win to win solution" for both speaker and addressee.

c. Politeness in Hierarchical Politeness System

Situation 5

(+P/+D/R Low)

Student asks lecturer to borrow his/her book

In this situation, ILF and NSF use indirect conventional strategy dominantly. Accordingly, ILF and NSF share the use of QCR (query preparatory) with slightly equal use of question sur la capacité (ILF 20\% - NSF 35\%), and great different number of use of question sur la permission (ILF 45\% - NSF 5\%)

1) Query preparatory with question sur la capacité:

ILF: Pourriez vous m'emprunter le livre dans le titre « pour lire le roman » madame? (R94)

'Could you lend me the book entitled "«pour lire le roman » madam?'

NSF: Est-ce que vous pourriez me le prêter, s'il vous plait? (R214)

'Could you borrow me, please?'

2) Query preparatory with question sur la permission:

ILF : Pourrais-je l'emprunter pour 2 jours, ...? (R86)

'Could I borrow it for 2 days?'

NSF: Pourrai-je vous l'emprunter? (R203)

'Could I borrow it from you?'

It is found that, again, ILF promote question sur la volonté (10\%). This type of question was not found in the data of native speakers of French in this situation.

Example:

3) Query preparatory with question sur la volonté:

Est-ce que vous voulez m'emprunter ce livre ? (R95)

'Would you like to lend me the book?'

There is strong evidence that ILF prefer to use want or need statement in request in high rank of imposition (20\%).

Je voudrais prêter un livre (R93) 
'I want to borrow a book'

This type of request is considered to be impolite especially when talking with person with higher power than speaker.

\section{Situation 6}

\section{(+P/-D/R High)}

Employee asks manager to borrow car

Similar to other requests, in this situation, ILF and NSF use indirect conventional strategy dominantly. Accordingly, ILF and NSF share the use of query preparatory with the use of question sur la capacité (ILF 25\% - NSF 55\%),

1) Query preparatory with question sur la capacité:

ILF : Pourriez vous me prêter la votre? (R118)

'Could you lend me yours?'

NSF : Pouvez-vous me prêter votre voiture? (R240)

'Can you lend me your car?'

There is a huge portion of use of question sur la permission realized by ILF (65\%) as shown in the following example.

Pourrais-je utiliser votre voiture?(R117)

'Could I use your car?'

To sum up, the similarities and the differences use of request strategies performed by Indonesian learners of French and Native Speakers of French can be seen on the figure 1.

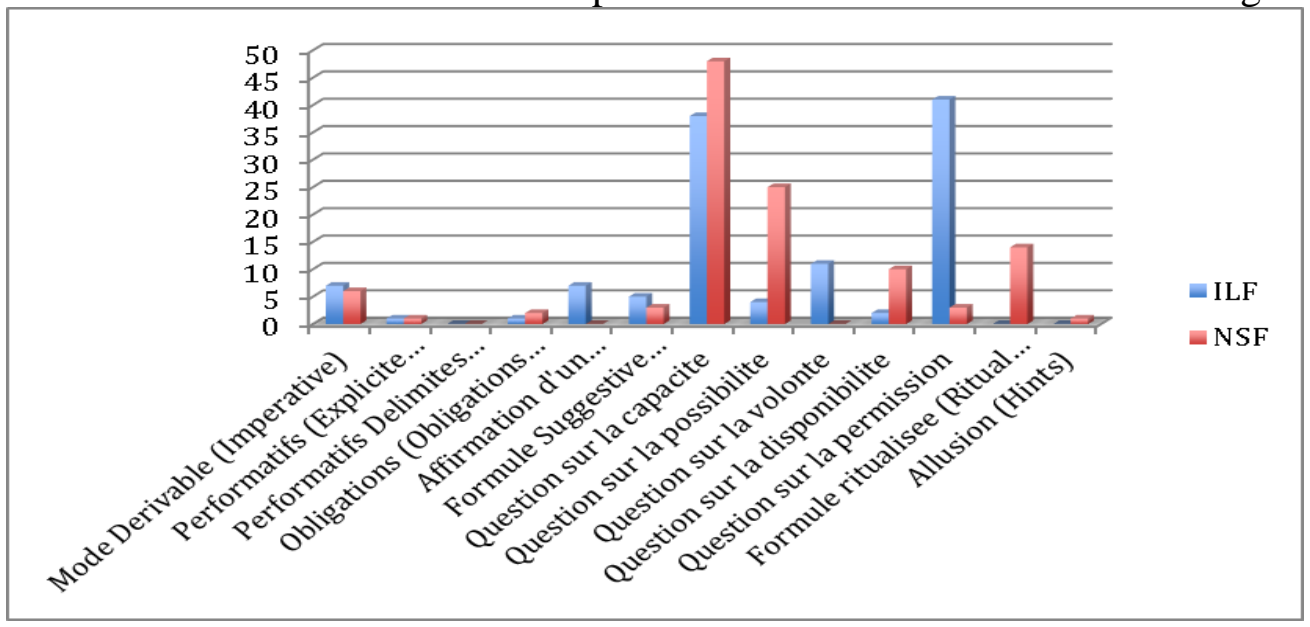

Figure 1. Request strategies performed by Indonesian learners of French and Native Speakers of French

Figure 1 shows that there are similarities of request strategies used by Indonesian learners of FLE and Native speakers of French. Both of groups share preferences firstly in the use of Indirect conventionneles especially the use of sub strategy of Préparation - Question sur une condition de réussite (QCR)/Query Preparatory sur la capacité (Pourriez-vous...), Formule suggestive/Suggestory formulae (si vous voulez ...?). Other similarity lies in the use of Direct formulation of Mode derivable/Imperatif (Va demander au piéton du bout de la rue, le chemin), Obligations/Obligation statements (Tu devrais demander à quel qu'un), and performatifs délimités/Hedged performatives (j'aimerais emprunter un livre...). Interestingly, both Indonesian learners of FLE and native speakers of French do not opt Performatifs/Explicit performatives in their requests.

Significantly, Data shows that there are s differences in the use of direct request especially in the sub strategy of Affirmation d'un désir ou d'une nécessité/Want or need 
statement (Je voudrais rester à votre maison...). Even in indirect conventionneles there are different use of sub strategy of Préparation - Question sur une condition de réussite (QCR)/Query Preparatory sur la possibilité (serait-ce possible d'emprunter l'un de vos livres?), sur la volonté (Voudriez vous m'aider?), sur la disponibilité (Auriez-vous la gentillese de me prêter la vôtre?), and sur la permission (Pourrais-je utiliser votre voiture?).

It is found also the use of Indirect conventionneles strategy of Formule riatualisée/Ritual formulation (Ça vous dérangerait de changer de place avec moi?) and Indirectes non-conventionneles strategy of Allusion/Hints (Si jamais elle est dispo, je le suis aussi) which are restrictedly found in Native speakers of French.

\subsection{Discussion}

Investigation on interlanguage pragmatics of politeness on requests of Indonesian learners of FLE and native speakers of French reveals that, firstly, there is a similarity of the strategies used in Indonesian learners and native speakers of French. Both of the groups undoubtedly tend to use conventionally indirect strategies to show politeness in their requests. The result of the study supported the evidences of previous studies in ILP arguing that conventionally indirect is the most preferred strategy used both by learners and native speakers of many languages. It is shown clearly in the research of Sukamto, 2012 (Indonesian requests by Korean learners), Bae, 2012 (French requests by Korean learners), FélixBrasdefer, 2005 (Mexican requests by Mexican students), Hassal, 2003 (Indonesian requests by Australian learners), Hendriks 2002 (English requests by Dutch learners of English). This confirms the seminal argument of Blum-Kulka (1987), and Trosborg (1995) stating that conventionally indirect strategies are the most preferred strategies chosen by both native speakers and learners of language learned. Furthermore, this strategy is chosen as the tools of minimizing the imposition of request. By delivering indirect request, both speaker and hearer has opportunity to save their face in accomplishing the act of request.

Errors analysis is a part of interlanguage study. Errors analysis focuses on the errors for produced by the second language learners in the target language (Bahar, 2019). The study conventionally indirect strategies are used by both groups under investigation in Deference politeness system where speaker has relatively less power than hearer, bigger distance, and with high and low ranking of Imposition (-P/+D/R High/low); Solidarity politeness system speaker has relatively less power than hearer, lower distance, and with high and low ranking of Imposition (-P/-D/R High/low) and in Hierarchical politeness system where speaker has relatively more power than hearer, bigger distance, and with high and low ranking of Imposition (-P/+D/R High/low).

However there is a different use of sub strategies made by ILF and NSF. Although both groups promote the massive use of query preparatory sub strategy but it is found that native speakers of French never use question sur la volonté in any request situations. In this case NSF tend not to intrude to positive face of addressee them. In contrast ILF promote the use of this strategy frequently.

In reverse, NSF prefer Formule ritualisée as a means to reduce the distance between speaker and addressee. They consequently deliberately use hints in situation with high rank of imposition. This strategy was never been employed by ILF in any request situation. Surprisingly ILF use Direct strategy of imperative regarding the request with high rank imposition. In line with that it seems that the strategy and that of want statement is considered polite by ILF. 
This research has allowed us to see that native French speakers, like most native speakers of Romance languages, tend to use indirect language as one of the preferred politeness strategies in formal, informal and hierarchical situations. The indirect wording reduces the obligations of the two interacting speakers and thus relieves them of direct responsibility by giving the interlocutor choices. The use of the indirect strategy can make a positive contribution for Indonesian FLE learners, since this type of strategy is often requested but because politeness is very contextual, there are possibilities that learners, influenced by their culture of origin, have the difficulty of choosing which strategies used and which modifications applied for such situations. Therefore, it is important for learners to be sensitive to boosting target cultures by taking advantage of the most frequent contacts with native speakers. Taking short course in France could be one of advantageous alternatives for Indonesian learners.

Hence, it is suggested that we devote more attention to developing Indonesian learners of French's pragmatic competence. It is therefore hoped that this research will help researchers focus on the numerous area of interlanguage pragmatics that are still understudied in FLE, but also show FLE educators and curriculum developers the importance of teaching L2 pragmatics.

Finally, this study is subject to certain constraints as the data were collected in the form of written discourse test completion. Dealing with spoken data may vary the results especially when comparing pronunciation of both groups under investigation.

\section{Conclusion}

It is concluded that in the deference politeness system, solidarity politeness system, and hierarchical politeness system there is a preference of Indonesian learners of FLE and native speaker of French to use Conventional Indirect strategy in their request. Eventually, this strategy, even realized in slightly different number of use is considered to be the most effective polite way to deliver a request. However there is a different use of sub strategies made by Indonesian learners of FLE and Native speakers of French. The politeness of the Request act is achieved mostly by the indirect strategy (Formulation indirecte) with the use of the interrogative sentence. The use of this type of strategy involves high level politeness. The commonly used sub-strategies are Query preparatory (QCR) by presenting (1) Question on the ability, it is the use of the interrogative sentence which asks the capacity of the interlocutor by using the verb "pouvoir" (can) (2) Question about the possibility; the use of the interrogative sentence which requires the possibility of the interlocutor.

\section{References}

Bae, J. A. (2012). La politesse dans la communication interculturelle: les stratégies de politesse utilisées par les coréens apprenant le français comme langue seconde lors des situations de demande. Thèse. Université de Montréal.

Bahar, Husain, D., and Aprianto, E. (2019). The Indonesian Syntactic Structure Interfere into English Sentences: An Interlanguage Study. Budapest International Research in Linguistics and Education Sciences (BirLE) Journal, 106-110

Bella, S. (2012). Pragmatic development in a foreign language: A study of Greek FL requests. Journal of pragmatics, 44(13), 1917-1947. 
Blum-Kulka, S. (1983). Interpreting and performing speech acts in a second language: A cross-cultural study of Hebrew and English. Sociolinguistics and language acquisition, 3655 .

Blum-Kulka, S. (1987). Indirectness and politeness in requests: Same or different?. Journal of pragmatics, 11(2), 131-146.

Blum-Kulka, S., House, J., \& Kasper, G. (1989). Cross-cultural pragmatics: Requests and apologies (Vol. 31). Ablex Pub.

Félix-Brasdefer, J. C. (2005). Indirectness and politeness in Mexican requests. In Selected proceedings of the 7th Hispanic linguistics symposium (Vol. 6678).

Grainger, K. (2011). Indirectness in Zimbabwean English: A study of intercultural communication in the UK. In Politeness across cultures (pp. 171-193). Palgrave Macmillan, London.

Hassall, T. (2003). Requests by Australian learners of Indonesian. Journal of Pragmatics, 35(12), 1903-1928.

Hendriks, B. C. (2002). More on Dutch English... please?: a study of request performance by Dutch native speakers, English native speakers and Dutch learners of English. [Nijmegen]: Nijmegen University Press.

Kasper, G. (1984). Pragmatic comprehension in learner-native speaker discourse. Language learning, 34(4), 1-20.

Kiesling, S. F., \& Johnson, E. G. (2010). Four forms of interactional indirection. Journal of Pragmatics, 42(2), 292-306.

Leech, G. N. (1983). Principles of pragmatics. Routledge.

Olshtain, E., \& Blum-Kulka, S. (1985). Degree of approximation: Nonnative reactions to native speech act behavior. Input in second language acquisition, 303325.

Reiter, R. M. (2000) Linguistic politeness in britain and uruguay: contrastive study of requests and apologies. Amsterdam/ Philadelphia: John Benjamins Publishing Company.

Scollon, R., \& Scollon, S. W. (2001). 27 Discourse and Intercultural Communication. The handbook of discourse analysis, 538.

Sukamto, K. E. (2012). Polite requests by Korean learners of Indonesian. Studies in Literature and Language, 5(2), 1-9.

Tannen, D. (2010). Abduction and identity in family interaction: Ventriloquizing as indirectness. Journal of Pragmatics, 42(2), 307-316.

Thomas, J. (1983). Cross-cultural pragmatic failure. 91-112.

Trosborg, A. (1995). Statutes and contracts: An analysis of legal speech acts in the English language of the law. Journal of Pragmatics, 23(1), 31-53.

Warga, M. (2005). «Est-ce que tu pourrais m'aider?» vs. « Je voudrais te demander si tu pourrais m'aider.» Les requêtes en français natif et en interlangue. Vox romanica, 64. 141-159. 